\title{
Insight
}

ChINA \& WTO ReV. 2018:2; 369-378

http://dx.doi.org/10.14330/cwr.2018.4.2.09

pISSN 2383-8221 • elSSN 2384-4388

\section{Ukraine's Way for Economic Rehabilitation through the Belt and Road Initiative}

Lester Paul*

Zhejiang Law School

Over the past ten years, the global economy has shifted from the US to emerging economies. This change may be due to emerging economies' shifting their focus from mainly manufacturing for western companies, to creating their own brands to compete with the likes of Apple. At the forefront of this shift is China. The US audit company, PwC in its latest report states: "China has already overtaken the US to be the largest economy based on GDP in PPP terms, and could be the largest valued at market exchange rates before 2030. Moreover, by 2042 the world economy could double in size with much of the growth fueled by emerging economies."1

This article is intended to highlight the benefits of China's Belt and Road Initiative and how Ukraine can co-operate with its neighbors to improve its economy as an alternative to the World Trade Organization ("WTO"). Ukraine has suffered several political setbacks over the past five years including the annexation of Crimea by its neighbor Russia. Recent political instability in Ukraine has made an adverse effect on the economy resulting from a steady decline in business. The benefits of the Belt and Road Initiative ("B\&R" or "OBOR") is analyzed and compared with the current investment and financial institutions available as a source of finance for the government. The result shows that there is a higher potential in the B\&R than in other trade partnerships. Ukraine should focus its capital on investing in its infrastructure and businesses that can quickly merge

* SJD candidate at Zhejiang University, LL.B.(Univ. of Guyana), LL.M. (Pace). ORCID: https:// orcid.org/0000-0002-8127-637X. The author may be contacted at: lesterpaul2692@gmail.com/ Address: 594 Hinsdale Street, Brooklyn, New York 11207 USA. 
with or capitalize on the Initiative.

Emerging economies such as Brazil, China, India, Indonesia, Mexico, Russia, Turkey and South Africa have been growing consistently over the past decade. By the year 2050, according to PwC, emerging economies at their current growth rate will be responsible for 50 percent of the world's GDP, while G7 members will decline to about 20 percent. ${ }^{2}$ The Chinese government has partly boosted the global economic shift with the introduction of the $B \& R$, which will further promote the logistics and productivity in many developing countries. ${ }^{3}$

Currently, the trade volume between the countries participating in the OBOR is estimated to be a quarter of all world trade. The number of countries involved in this Initiative does not make up a quarter of the world's countries and many are considered developing countries. By December 31, 2017, however, the AIIB, through its board, had given the green light for twenty four projects in fourteen of the AIIB's member countries. ${ }^{4}$ The total cost of the twenty four projects is said to be estimated at 1.07 billion USD. ${ }^{5}$ The magnitude of the investment is a testament to the long term commitment to the AIIB and B\&R by the Chinese government and its stake holders. Countries in Central Asia and Eastern Europe will be the primary beneficiaries depending on the falling trade cost.

The biggest hindrance to the OBOR is the willingness of countries to invest in their economies in anticipation of the complete removal of most or all trade barriers between member countries. There are over 2,200 transportation projects in more than 18 countries, which include sea and dry ports, roads, and railroads with supporting bridges as seen on- ReconnectingAsia.CSIS.org. ${ }^{6}$ B\&R is expected to expand significantly to oil pipelines, power plants, telecommunications and other infrastructure projects that will improve connectivity.

However, non-B\&R countries are not limited from capitalizing on it, they are free to enter into treaties, such as Bilateral Investment Treaties ("BITs"). Entering into BITs with neighboring countries who are part of $B \& R$ can give indirect access to the benefits of the Initiative. Eastern European countries are best suited to cooperate with each other by upgrading their interconnecting infrastructure to move raw materials and finished goods to a country such as Poland who is a member of the OBOR.

Although China's breathtaking economic growth over the past thirty years is slowing down, it is still faster than the rest of the world's economies. Unlike 
other countries, China's slower economic growth is partially self-induced as it tries to refocus its economy to be more service-based, shifting from its former manufacturing-based economy. Another reason why this slowdown is not so troubling is that China has several big multibillion-dollar projects in the pipeline. ${ }^{7}$ China expects that when these projects start to bear fruit, those who were not on board from the onset will regret it.

One of the noticeable projects is the AIIB. Those countries who participated in the establishment of the AIIB as stakeholders acknowledged that the US-led postwar financial system - IMF and the World Bank - would be no longer the primary source of the world's development capital. ${ }^{8}$ Within months twenty-seven countries had signed up to become founding members of the AIIB. They came from New Zealand (OECD States), Southeast Asia (Brunei, Cambodia, Indonesia, Laos, Malaysia, Myanmar, the Philippines, Singapore, Thailand and Vietnam), South Asia (Bangladesh, India, Maldives, Nepal, Pakistan and Sri Lanka), Middle East (Jordan, Kuwait, Oman, Qatar and Saudi Arabia), Central Asia (Kazakhstan, Tajikistan and Uzbekistan), and Mongolia. ${ }^{9}$

On March 15, 2015, the UK also signed on to the AIIB which at the time seemingly angered the US who months earlier stated that "there is no need for such a bank and that it would undermine the work done by the IMF and the World Bank." "10 To support their condemnation, Secretary of US Treasury Department Jack Lew, stated: "New players are challenging US leadership in the multilateral system. ${ }^{11}$ If signatories are a positive sign, then the AIIB is an early success against the strong opposition of the US which is a rare case in the postwar era. The US went on to argue that this was "a trend of constant accommodation of China." In the face of these US objections, France, Germany, and Italy signed on it, not allowing a week's time for the US to cool down from Britain's signature. Japan is the only economic power siding with the US for strategic purposes. Japan did not change its stance, questioning the Bank's management. ${ }^{13}$

The US' objections proved to be even more futile because, by the end of March 2015, which marked the deadline for founding members to sign up, a total of fifty-seven countries had applied for membership. These included twelve European countries (Austria, Denmark, Finland, Luxembourg, the Netherlands, Norway, Sweden, and Switzerland, in addition to the four, mentioned earlier) as well as Australia, Brazil, Egypt, Georgia, Kyrgyzstan, Russia, South Korea and 
Turkey. Most notably, Russia signed as an ally to China as well as a member of the de facto "anything other than America" movement.

The Eastern European Bloc has a long history associated with a vibrant culture, despite this the region's communist past often overshadows its history. The current boundaries of what is now Eastern Europe took form during the final months of bloodshed of World War II. The region includes all territories once part of the former Soviet Bloc. The economic hardships endured by these countries were due to the Soviet Economic model which existed as an economic entity focusing on financing its war machine in anticipation of the Cold War evolving into an all-out war. During the Soviet era, capitalism was frowned upon, and any form of trade or commerce with the West was looked at with high suspicion and in most cases stifled. $^{14}$

The Iron Curtain fell down in 1989, revealing the economic landscape of Eastern Europe. As most feared, it was barren, and in most cases the mode of production was antiquated. Many Eastern European countries that had once been part of the Soviet Union ("USSR") started to build a free enterprise system and re-evaluate their economic alliances. Among the countries are Belarus, Bulgaria, Estonia, Hungary, Lithuania, Latvia, Moldova, Poland, Romania, and Ukraine. In 1993, Czechoslovakia was peacefully separated, forming two sovereign states - the Czech Republic and Slovakia, both of which formed the bulk of Eastern Europe. Some of these countries joined the European Union in a quest for economic prosperity. ${ }^{15}$ In this course, some countries like Poland readjusted its economic strategy towards the western model, while others such as Ukraine remained heavily dependent on Russia. In retrospect, it could be argued that Russia saw this dependancy as a weakness to be exploited, and as a motivational factor in the alleged orchestration of the invasion of Ukrainian territory. Needless to say, this invasion, however it came about, has caused the economy to decline. Alignment with Russia arguably has proven to be a mistake.

Western Europe, as a whole, has a higher GDP per capita than the global average; the countries in this region have well developed economies. ${ }^{16}$ None the less, many Eastern European countries are struggling to live up to the economic expectations of their western neighbors. Among them are, Belarus, Georgia, and Ukraine who can all trace their economic woes back to the USSR era.

The question for many Eastern European countries to ask themselves is what 
has the West done for Eastern Europe and is the West in any economic position to help out? Two global options are the Trans-Pacific Partnership ("TPP") and the WTO. However, both differ from B\&R given that the Initiative has the full weight of the Chinese government and its people behind it. B\&R comes with an estimated price tag of USD 5 trillion, most of it financed by China and more concretely the AIIB which has a deposit of more than USD 65 billion. ${ }^{17}$

\section{Figure 1: One Belt, One Road Intiative ${ }^{18}$}

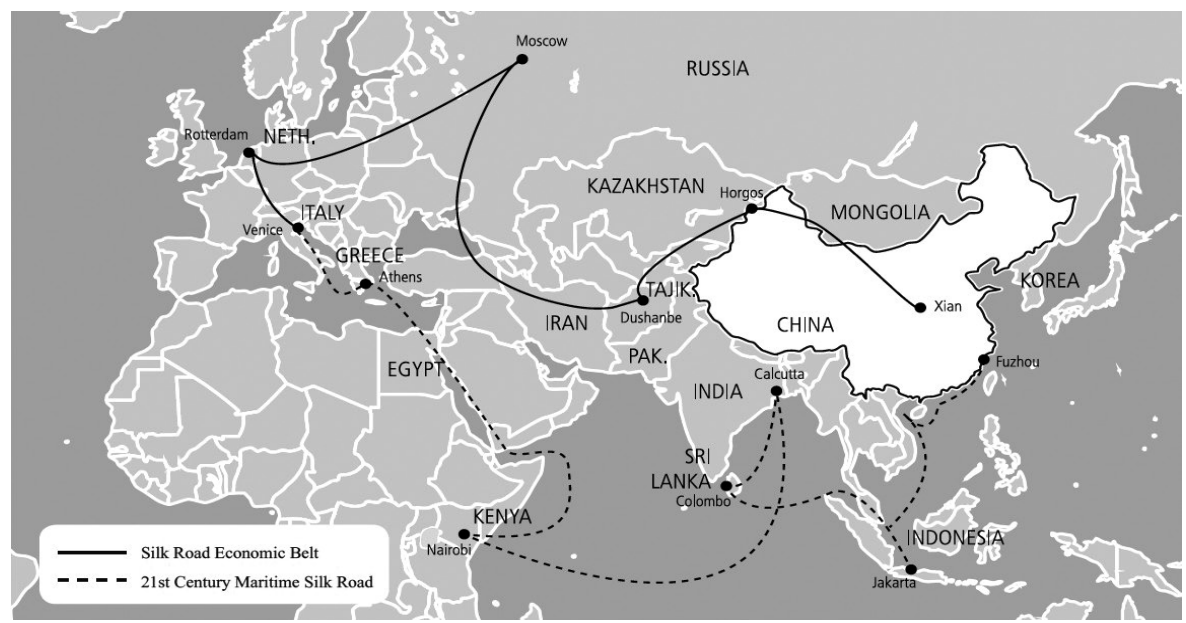

Belarus, Poland, and Russia are Ukraine's neighbors and part of the OBOR. Although the OBOR does not pass directly through Ukraine's territory, Ukraine can access the OBOR through its neighbors. Ukraine should answer the following questions before integrating itself into the Initiative:

- Can Ukraine convince China that it is important enough for China to re-draw the OBOR map?

- If Ukraine cannot bring the OBOR to its territory how can Ukraine go to the OBOR?

- Can Ukrainian companies supply spare parts for machinery, trains, and other forms of transportation involved in the construction an development of the OBOR?

- Can Ukrainian companies be part of the logistics supply for the project? 
- Once the OBOR is operational, can Ukrainian companies supply food and maintenance services for the trains and railroads, and their workers?

- Can Ukraine work with its neighbors to build roads and railways connecting the country to the OBOR?

- What products does Ukraine have that is in demand by the countries along the OBOR?

- What new industries can Ukraine develop or what industries can be rebuilt to cater to the OBOR?

- Can Ukraine use the OBOR to establish new markets for its products?

- Would it be beneficial to sign Bilateral Investment Treaties (BITs) with countries along the OBOR?

This list does not exhaust all the possibilities but sheds some light on what needs to be done by Ukraine and other Eastern European countries. President Xi Jinping stated that the OBOR "should be jointly built through consultation to meet the interests of all, and efforts should be made to integrate the development strategies of the countries along the route. It is not closed, but open and inclusive; it is not a solo by China but a chorus of all countries along the route." ${ }^{19}$ These words serve as an invitation for cooperation. Considering China's reputation for its willingness to do business with developing nations, Ukraine will only have itself to blame if it allows this opportunity to slip away. Some of the benefits to be gained are:

- A greater inflow of cash from the increased spending power of Ukraine's neighbors;

- Reduced logistics cost to get Ukrainian products to Asia, Africa and the rest of the world;

- Increased Tourism;

- Help to foster economic and diplomatic cooperation between Ukraine and its neighbors;

- Ukrainian companies will have cheaper access to raw materials;

- Provide Ukrainians with a more extensive variety of goods and services, while reducing the cost of living for ordinary Ukrainians; and

- Make traveling easier for ordinary Ukrainians.

All these benefits will help Ukraine to be more independent from Russian economic influence and to rebuild its economy from the loss it suffered from the annexation of Crimea by Russia. The Ukrainian government estimates the cost of 
losing Crimea is approximately Euros 4 billion. ${ }^{20}$

The loss of Crimea was a devastating blow to the Ukrainian economy, not only did they lose valuable territory but also showed how weak they are militarily and economically in comparison to Russia. What compounds the loss is the fact that NATO, the rest of Europe and America did little or nothing to assist. ${ }^{21}$ The reasons for not helping may vary. However, an educated assumption would be that defending Ukraine was not worth the risk economically or politically. If Crimea can serve as an example, then it can be deduced that NATO and the West are allies only when it benefits them strategically.

To sum up, it is not merely about money, but full independence and alliances through economic ties that will bind Ukraine to other post-soviet countries. Such economic alliances will bring other sister countries to work together even if Russia at any time reclaims in whole or in part any of the breakaway territories as was done in Crimea. Russia was able to annex Crimea mainly because Ukrainians loyal to Russia saw Russia as a better source of economic stability than Ukraine, whose economy is currently on the decline. A stronger economy would limit the incentive of Russian money. Also, if Ukraine connects itself to the OBOR chain, then China would find it economically significant to support Ukraine in its time of need. China has a long history of none intervention in international affairs, but would speak up when its core national interests are being affected. Russia would listen to China's request more seriously than that of the US or Western European countries which maintained hostile relationship for decades.

It would be wise for all Eastern European countries to hitch their wagons to China and be less dependent on western organizations like the WTO and the IMF if they seek economic independence from Russia. 


\section{REFERENCES}

1. PwC maintains: "The long-term global economic power shift away from the established advanced economies is set to continue over the period to 2050, as emerging market countries continue to boost their share of world GDP in the long run despite recent mixed performance in some of these economies." See The shift of global economic power to emerging economies set to continue in the long run, with India, Indonesia, and Vietnam among star performers, PwC, Feb. 7, 2017, available at https://www.pwc.com/hu/en/pressroom/2017/shift_of_global_ economic_power.html (last visited on July 30, 2018).

2. Id. The report projects that "the world economy could double in size by 2042 , growing at an annual average real rate of around $2.5 \%$ between 2016 and 2050. This growth will be primarily driven by emerging market and developing countries, with the E7 economies of Brazil, China, India, Indonesia, Mexico, Russia and Turkey growing at an annual average rate of around $3.5 \%$ over the next 34 years, compared to only around $1.6 \%$ for the advanced G7 nations of Canada, France, Germany, Italy, Japan, the UK and the US.” Csaba Polacsek, Financial Services Advisory Leader at PwC Hungary comments: "We will continue to see the shift in global economic power away from established advanced economies towards emerging economies in Asia and elsewhere. The E7 could comprise almost $50 \%$ of world GDP by 2050, while the G7's share declines to only just over $20 \%$."

3. Id.

4. See Belt and Road Initiative for shared benefit, not being imposed: AIIB, INDIAN EXPRESS, Mar. 4, 2018, available at https://indianexpress.com/article/world/belt-and-road-initiative-forshared-benefit-not-being-imposed-aiib-5085579 (last visited on July 30, 2018).

5. Id.

6. M. Green, China's Maritime Silk Road, Strategic and Economic Implications for the IndoPacific Region, CSIS Reports, Apr. 3, 2018, available at https://reconnectingasia.csis.org/ analysis/entries/chinas-maritime-silk-road-strategic-and-economic-implications-indo-pacificregion (last visited on July 30, 2018).

7. Consulate-General of PRC in Chicago, China announces multi-billion-dollar infrastructure projects, higher export rebates to stimulate the economy, available at http://www. chinaconsulatechicago.org/eng/ywzn/sw/t522014.htm (last visited on July 30, 2018).

8. Id.

9. Baker McKenzie, Belt \& Road: Opportunity \& Risk: The Prospects and Perils of Building China's New Silk Road, available at https:/www.bakermckenzie.com/-/media/files/insight/ publications/2017/10/belt-road/baker_mckenzie_belt_road_report_2017.pdf?la=en (last visited on July 30, 2018).

10. M. Pizzi, Europe's economic powerhouses snub the US, sign up to China-led 'world bank,' AljazeEra, Mar. 17, 2015, available at http://america.aljazeera.com/articles/2015/3/17/ europe-defies-us-signs-on-to-chinas-world-bank.html (last visited on July 30, 2018). 
11. Id. In a prepared statement on the IMF reform that happened to coincide with the AIIB developments, Treasury Secretary Jack Lew warned Congress: "Our international credibility and influence are being threatened."

12. M. Bird, The White House is slamming Britain for appeasing China's rising power, Bus. INSIDER, Mar. 13, 2015, available at https://www.businessinsider.com/us-attacks-britainconstantly-accommodating-china-2015-3? $\mathrm{r}=\mathrm{UK} \& \mathrm{IR}=\mathrm{T}$ (last visited on July 30, 2018). It states: "The front page of the Financial Times ... carries an amazing splash with a rare diplomatic tension between the highest levels of the British and American governments - the UK government stands accused of 'constant accommodation' of China as a rising power."

13. Kong Defang \& Yao Chun, Why the US and Japan question AIIB, People's Daily, Apr. 17, 2015, available at http://en.people.cn/n/2015/0427/c98649-8884144.html (last visited on July 30, 2018).

14. See Embargoes and Sanctions - Cold war sanctions, Encyclopedia of New American Nation, available at http://www.americanforeignrelations.com/E-N/Embargoes-and-SanctionsCold-war-sanctions.html (last visited on July 30, 2018).

15. See Soviet Republic and EU, Human Science, available at http://humanscience.wikia.com/ wiki/Soviet_Republic_and_EU (last visited on July 30, 2018). It states: "In the final decades of its existence, the Soviet Union consisted of fifteen Soviet Socialist Republics (SSR), often called simply Soviet Republics. Within the USSR they were also called union republics (Russian: союзные республики, soyuznye respubliki). All of them were considered to be socialist republics. Except for the Russian SFSR, they had their communist parties, part of the Soviet system. All of the former Republics are now independent countries, with twelve of them (all except the Baltic states) being very loosely organized under the heading of the Commonwealth of Independent States."

16. C. On, Richest and Poorest EU Countries, AALEP, Dec. 8, 2017, available at http://www. aalep.eu/richest-and-poorest-eu-countries (last visited on July 30, 2018). "Based on IMF data for per capita GDP, adjusted for purchasing power parity (PPP). GDP-PPP makes for a better comparison of living standards because PPP takes into account the cost of living and inflation rates, rather than just exchange rates, which may distort the real differences in income."

17. Zheping Huang, One Belt, One Road: Your guide to understanding OBOR, China's new Silk Road plan, QUARTz, May 15, 2017, available at https://qz.com/983460/obor-an-extremelysimple-guide-t (last visited on July 30, 2018).

18. Bomin Ko, Uneasy Days of Push-and-Pull between China and the WTO: Recent Issues of China in the WTO, 1 CHINA \& WTO REv. 114, Figure 1 (2015). Reproduction of this map has been duly permitted by YIJUN Press.

19. E. Michael Mitchell Omoruyi, Building the road of sharing new opportunities and prosperity, ChInA Daily, June 6, 2017, available at http://www.chinadaily.com.cn/opinion/2017beltand road/2017-06/02/content_29598721.htm (last visited on July 30, 2018). 
20. Staff reporter, Ukraine puts economic cost of losing Crimea at $€ 8$ billion. Kiev to file compensation claims with international courts over the annexation of Crimea, IRISH TIMES, Apr. 7, 2014, available at https://www.irishtimes.com/business/economy/ukraine-putseconomic-cost-of-losing-crimea-at-8-billion-1.1753182 (last visited on July 30, 2018).

21. K. Volker, Where's NATO's Strong Response to Russia's Invasion of Crimea?, ForeigN PoL'y, Mar. 18, 2014, available at https://foreignpolicy.com/2014/03/18/wheres-natosstrong-response-to-russias-invasion-of-crimea (last visited on July 30, 2018). It states: "No NATO territory has been invaded by Russia, so NATO's collective defense commitment has not been formally tested. But NATO allies in the East - the Baltic States and Poland, for example - are rightly worried about Moscow's intentions. And, perhaps even more importantly, non-allies - such as Moldova, Georgia, Ukraine, and Azerbaijan - are watching to see whether NATO pushes back, or accedes to a revived Russian sphere of influence over pieces of the former Soviet Union." 